\title{
EXPletives in Modern Persian
}

\author{
Abolfazl MOSAFFA JAHROMI \\ Jahrom University, Iran \\ a.mosaffa.jahromi@gmail.com
}

\begin{abstract}
It has generally been argued that Persian does not include dummy elements called expletives, in spite of the existence of the morpheme in which shows the behavior of an expletive in specific constructions. The morpheme is not a part of the argument structure and has no meaning. In Persian, which is a pro-drop language, the morpheme in as expletive is generated only in [SPEC $\mathrm{CP}$ ] of an independent clause. This element may occur in a subject position, object position, or as an object of a preposition. In subject and object positions it is optional when $S^{\prime}$ moves to the end of the sentence, or is adjoined to it, in other cases it is obligatory. As an object of a preposition it is always obligatory, no matter whether the structure is the result of a movement or not. The aim of this article is to provide evidence in favor of the existence of expletives, and their projection in Persian.
\end{abstract}

\section{Keywords}

predicate logic, expletives, projection principle, theta criteria

\section{Izvleček}

V jezikoslovju prevladuje miselnost, da perzijščina ne vsebuje mašil, navkljub obstoju morfema

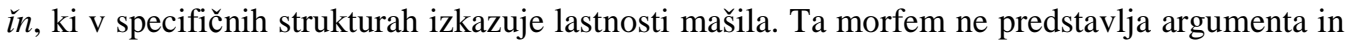
ne nosi pomena. V perzijščini, ki spada med "pro-drop" jezike (tj. nekateri zaimki so lahko pod določenimi pogoji izpuščeni), se morfem $\check{~} n$ pojavlja le v strukturi [SPEC CP] neodvisnega stavka, in sicer kot osebek, predmet ali pa kot predložni predmet. V primeru, ko je $S^{\prime}$ na koncu stavka, oz. mu je le-ta priključen, je morfem $\check{\text { nn }}$, ki nastopa kot osebek ali povedek, poljuben, $\mathrm{v}$ vseh drugih primerih je obvezen. Kot predložni predmet je vedno obvezen. Namen tega članka je pokazati obstoj mašil teoretično in na konkretnih primerih.

\section{Ključne besede}

predikativna logika, mašilo, princip projekcije, theta kriterij 


\section{Introduction}

Within generative grammar, counting everything from the principle-andparameters approach to the recent minimalist approach, the existence of expletives in pro-drop languages has been commonly assumed (e.g. Burzio, 1986; Chomsky, 1995). ${ }^{1}$ Dutch and Italian, for example, are among pro-drop languages, and allow expletives to be generated in their architecture of grammar (cf. Reuland, 1988; Brandner, 1993). Current work on the syntax of expletive "there" in English has largely focused on theoretical problems which expletive "there" poses with regard to agreement, case and thematic roles (Chomsky, 1995, 1993; Lasnik, 1995; Groat, 1995). Chomsky (1995, 1993) focuses on LF-Affix analysis and Lasnik (1995) on partitive case analysis. Koeneman and Neeleman (2001) argue that predication theory is instrumental in capturing the distribution of expletives.

Following Jackendoff's (1997, 2002) notion of defective lexical item, I define expletives as words with syntactic properties but with no semantic content. Projection of such dummy elements has generally been in veil in Persian. Mahootian (1997, p. 48) posits that Persian does not allow dummy subjects. Karimi (2005, p. 77) posits that there are no overt expletives in Persian, and also that there is no evidence to assume the existence of covert expletives in this language. Moreover, no independent report of expletives in Persian can be found in books devoted to generative view, such as Miremadi (1977) for example.

The aim of this article is to support the view that expletives are generated in this language. One of the reasons for the neglect or overlook of these elements in Persian is argued to be the existence of a homophonous morpheme, which is morphologically similar to an expletive. Morpheme in "this", which behaves like a pronoun and occurs either in a subject position, object position, or as an object of a preposition, is likely to be mistaken for a free morpheme $\check{\imath}$, which is null, and this is indeed what has been the line of reasoning when assuming expletives. In addition to morphological similarity, the effect of writing system and pro-drop nature of Persian can be mentioned as the other sources for the neglect of these non-argument elements. This article attempts to provide evidence in support of the existence of expletives as dummy elements in Persian, and predicate logic is thought to play fundamental role in paving the way for generating these elements in [SPEC CP] of independent clauses.

\section{Predicate Logic and Expletives}

Predicates are words which do not belong to any referring expressions. Some predicates are one-place predicates requiring only one argument (like "sleep"), some

\footnotetext{
${ }^{1}$ The same has not usually been the case for topic-drop languages like Japanese and Korean for which the theoretical necessity of expletives has rarely been discussed.
} 
are two-place predicates requiring two arguments (like "kill"), and some are threeplace predicates requiring three arguments (like "give") (Hurford \& Heasly, 1996). Intransitive verbs correspond to one-place predicates with only one argument, and transitive verbs of traditional syntax correspond to at least two-place predicates taking two or more arguments. Satisfying argument structure of the verb results in a grammatical sentence of that language, and any further addition of arguments would make such sentence ungrammatical, as exemplified below.

The verb "surprise" takes two arguments, one in a subject position and undertaking a role of an actor, and another in an object position with a role of a patient. The result is a grammatical sentence:

\section{(1) John surprised Julia.}

It is crucial to notify that every verb has only one argument structure, but not all arguments of a predicate are necessarily realized as NPs, and some NPs in the subject position of a sentence are not assigned a thematic role; hence, they are not arguments.

(2) It surprised Julia that the Earth is round.

In this sentence the NP "it" is not assigned a theta role and should not be considered as an argument because every verb has only one argument structure. The verb "surprised" is a two-place predicate which assigns two theta roles, one to the object "Julia" and the other to the $S$ ' "that the Earth is round". In case "it" in a subject position were considered as a part of an argument structure, a verb would be allowed to have two or more argument structures, which is against the set rules. Hence, "it" is supposed to be a special element with no argument structure and receiving no theta role. In other words, it is an expletive. Though there have yet been no reports on such elements and their syntactic behavior, the following data ramifies evidence in support of expletives in Persian, contrary to the literature (cf. Karimi, 2005) that argue against the existence of these syntactic elements.

\section{Expletives in Subject Position}

Persian is a pro-drop language with canonical SOV word order. The unmarked position of an object in Persian is in front of a verb, and there is an object marker ră which distinguishes subjects from objects. It is also possible to put object before subject in more marked constructions. In order to prove the existence of expletives in Persian one should pay attention to the argument structure of the verbs that can take such elements.

The verb moteajjeb kardaen (to surprise) is a two place predicate in Persian which takes two NPs as its arguments: 


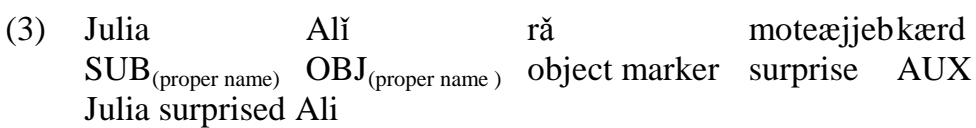

An additional argument in a sentence results in ungrammaticality since every NP has to receive one theta role, and an extra argument can receive none. Ungrammaticality of the following example is due to the projection of $i n$ as one of the arguments of the verb moteajjeb kard without a theta role.

(4) * ǐn Julia Alǐ ră moteæjjeb kærd this (it) SUB OBJ object marker surprise AUX

However, it is possible to realize one of the arguments not as a NP but as an $\mathrm{S}^{\prime}$.

(5) inn $\left[\mathrm{S}^{\prime}\right.$ ke zæmin gerd ast] Julia ră moteæjjeb kærd it $\mathrm{COMP}_{\text {(that) }}$ Earth round is OBJ obj-marker surprised AUX It surprised Julia [ $\mathrm{S}^{\prime}$ that the Earth is round]

The verb "to surprise" is a two place predicate which is assigned two theta roles. However, the presence of in in Persian is problematic because its grammar has projected an element which filters out case filter. The constituent $\check{i n}$ receives no case and hence this sentence should be ungrammatical. As it is the case that every verb has only one argument structure, this element is problematic in the architecture of grammar proposed by generative gramar. In fact, pronoun $\check{i n}_{n}$ in Persian contributes nothing to the meaning of a sentence, so $\check{i n}$ plays no role in a semantic make-up of such a sentence. Its presence is required simply for structural reasons. Such a dummy pronoun is often called an expletive pronoun.

Expletives are elements constituting NPs which are not arguments and to which no theta role is assigned. If we replace $i n$ with some other NP which requires a theta role, the result is ungrammaticality because one of the arguments receives no theta role, as shown in the following sentence.

(6) *ǔ [S' ke zæminn gerd æst] Julia ră moteæjjeb kærd he $\operatorname{COMP}_{\text {(that) }}$ Earth round is OBJ obj-marker surprised AUX

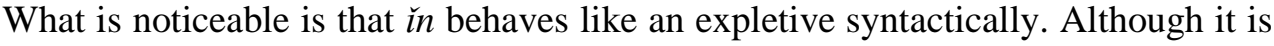
a dummy element, referring to no meaning, Persian does not allow $S^{\prime}$ in a subject position without the expletive ${ }^{\prime} n$. In other words, it is ungrammatical to use $S^{\prime}$ as a subject without an expletive, as shown in the next example.

(7) * [ $\mathrm{S}^{\prime}$ ke zæmin gerd æst $]$ Julia ră moteæjjeb kærd $\mathrm{COMP}_{\text {(that) }}$ Earth round is OBJ obj-marker surprised AUX 
Ungrammatical sentence without an expletive in a subject position can turn into a grammatical sentence if $\mathrm{S}^{\prime}$ moves and adjoins to VP at the end of the sentence, as in the following example:

(8) Julia ră moteæjjeb kærd [ $\mathrm{S}^{\prime} \mathrm{ke}$ zæmǐn gerd æst] OBJ obj-marker surprised AUX $\mathrm{COMP}_{\text {(that) }}$ Earth round is (It) surprised Julia that the Earth is round

Constructions in which $S^{\prime}$ has been moved rightward without the help of an expletive, like in the sentence above, can be used with such elements at the end, too. In other words, the expletive $\check{~}{ }^{n}$ and $\mathrm{S}^{\prime}$ are allowed to occur after the verb.

(9) Julia ră moteæjjeb kærd in [ $\mathrm{S}^{\prime} \mathrm{ke}$ zæminn gerd æst] OBJ obj-marker surprised AUX it $\mathrm{COMP}_{(\text {(that }}$ Earth round is It surprised Julia that the Earth is round

It is also feasible to analyze dummy elements in a subject position phonetically. $\mathrm{S}^{\prime}$ is adjoined at the end:

(10) in Julia ră moteæjjeb kærd [ $\mathrm{S}^{\prime}$ ke zæmin gerd æst] it OBJ obj-marker Surprised AUX $\operatorname{COMP}_{\text {(that) }}$ Earth round is It surprised Julia that the Earth is round

The obligatory nature of the presence of expletive is due to the extended projection principle (Chomsky, 1982, p. 10) which requires the subject position to be filled.

Some more examples of predicates which project an expletive in a subject position are:

(11) two-place predicates nărăhæt kærdæn (to bother) negarăn kærdæn (to worry) ghæmgǐn kærdæn (to make sad) šădăb/šăd kærdæn (to make happy)

(12) one-place predicates mohem bǔdæn (be important) jăye taæssof bŭdæn (be sorry) lăzem bǔdæn (be necessary) jăleb bŭdæn (be interesting) 


\section{Expletives in Object Position}

The occurrence of expletives in Persian is not limited only to a subject position, it is also found in an object position ${ }^{2}$, as in the following example. $\mathrm{S}^{\prime}$ has been adjoined sentence-finally, the dummy element $\check{\imath}$ is followed by the object marker ră:

(13) Julia ǐn ră mǐdănæd [ $S^{\prime}$ ke zæminn gerd æst] OBJ it obj-marker know COMP (that) Earth round is Julia knows that the Earth is round.

There are several other structures including expletives in an object position:

(14) Julia inn [ $S^{\prime}$ ke zæminn gerd æst] ră mǐdănæd OBJ it $\operatorname{COMP}_{\text {(that) }}$ Earth round is obj-marker know Julia knows that the Earth is round.

(15) *Julia [ $\mathrm{S}^{\prime}$ ke zæmǐn gerd æst] ră mǐdănæd OBJ $\operatorname{COMP}_{\text {(that) }}$ Earth round is obj-marker know

(16) *Julia ǐn $\left[S^{\prime}\right.$ zæmǐn gerd æst $]$ ră mǐdănæd OBJ it Earth round is obj-marker know

In an object position, the presence of both the expletive and the complementizer is necessary. Though the expletive $\check{~} \check{n}$ is not optional in object position, it may be omitted in cases when $S^{\prime}$ moves to the end of $S$ as the following examples indicate:

(17) Julia mǐdănæd [ $S^{\prime}$ ke $\quad$ zæmǐn gerd æst] OBJ know $\mathrm{COMP}_{\text {(that) }}$ Earth round is Julia knows that the Earth is round.

(18) Julia ǐn ră mĩdănæd [ $S^{\prime}$ ke zæmǐn gerd æst] OBJ it obj-marker know $\operatorname{COMP}_{\text {(that) }}$ Earth round is Julia knows that the Earth is round.

(19) *Julia ǐn mǐdănæd [ $S^{\prime}$ ke zæminn gerd æst] OBJ it know $\mathrm{COMP}_{(\text {that }}$ Earth round is

The conclusion which may be drawn from the above examples is that the expletive in is optional in an object position under the condition that both the expletive and the object marker are omitted. The above sentences are the result of a movement of $\mathrm{S}^{\prime}$ and the adjunction to the end.

However, in base generated structures which are not the result of such a movement, expletives and object markers exhibit different syntactic behavior. It is impossible to omit an object marker after $S^{\prime}$ without loosing grammaticality of the whole sentence. The obligatory nature of expletives after $S^{\prime}$ has been shown in the following examples:

\footnotetext{
${ }^{2}$ See Postal and Pullum (1988) for example sentences with anticipatory object "it" in English.
} 
(20) Julia ǐn $\left[S^{\prime}\right.$ ke zæmǐn gerd æst] ră midanad OBJ it $\mathrm{COMP}_{\text {(that) }}$ Earth round is obj-marker know Julia knows that the Earth is round.

(21) *Julia ǐn [ $S^{\prime}$ ke zæmin gerd æst] midanad $\mathrm{OBJ}$ it $\mathrm{COMP}_{\text {(that) }}$ Earth round is know

Below is a list of some more verbs that subsume expletives in an object position:

(22) hæds zædæn (to guess)

ommǐdvăr bǔdæn (to hope)

pǐshnehăd kærdæn (to offer)

færămūš kærdæn (to forget)

be yăd ăværdæn (to remember)

\section{Expletives as Objects of Preposition}

In Persian, expletive $\check{\text { } n}$ may also occur after prepositions:

(23) Julia be in $\left[S^{\prime}\right.$ ke zæmin gerd æst] fekr kærd OBJ PREP (to) it COMP $_{(\text {that }}$ Earth round is thought AUX Julia thought that the Earth is round.

(24) Julia be in fekr kærd [ $S^{\prime}$ ke zæminn gerd æst] OBJ PREP $_{(\text {to) }}$ it thought AUX COMP(that) Earth round is Julia thought that the Earth is round.

The syntactic behavior of an expletive after prepositions differs from its behavior in other positions; its presence is obligatory. The obligatory nature of the presence of expletives after prepositions can be ascribed to the fact that PP is not a part of the argument structure of the verb, i.e. it is an adjunct.

(25) *Julia be $\quad\left[\mathrm{S}^{\prime} \mathrm{ke}\right.$ zæmin gerd æst] fekr kærd OBJ PREP(to) $\operatorname{COMP}_{(\text {that }}$ Earth round is thought AUX

(26) *Julia be fekr kærd [ $\mathrm{S}^{\prime} \mathrm{ke}$ zæminn gerd æst] OBJ PREP(to) thought AUX $\operatorname{COMP}_{(\text {that })}$ Earth round is

The important characteristic of the expletive in after prepositions is that it refers to nothing in the external world. If it were the case that it could refer to something beyond the sentence, its existence as an expletive would be questionable.

\section{Neglect of Expletives in Persian}

Up to this point several examples have been introduced to support the view that expletives are generated in Persian. One of the reasons why both, the traditional 
grammar as well as modern linguistic studies have neglected the existence of this constituent in Persian may be found in the writing style. The consequence of writing on leading into ignoring dummy elements implicitly when assuming them. Expletive in and the following complementizer in Persian are written as one word $̌ n k e$ and as such have always been interpreted as one constituent. There seem to be no literature where inke would be treated as two different syntactic constituents, one as an expletive and the other as a complementizer.

$$
\begin{aligned}
& \text { (27) Julia be [ } S^{\prime} \text { inke zæmǐn gerd æst] fekr kærd }
\end{aligned}
$$

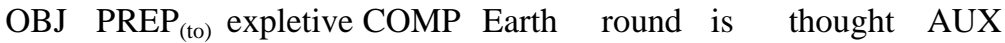

$$
\begin{aligned}
& \text { Julia thought that the Earth is round. }
\end{aligned}
$$

Another feasible reason for the neglect of these elements lies in the fact that there exists another similar constituent in Persian which, when proceeding a noun, functions differently from expletives. This constitute is not semantically void (as in ı̌n ketăb "this book"; in moerd "this man"), and according to Lyons (1996) has its own deictic meaning. Expletives, as presented in this paper, have always been ascribed to the category of a noun, and this conception has gained dominance in syntactic argumentations.

Yet another reason can be found in the pro-drop nature of Persian language, which allows expletives to be phonetically empty. It is significant to note that expletive $\iota_{n}$ has an allomorph ăn, which has the same distribution as $\check{\imath}$. The use of $\check{\imath}$ is more frequently found in a spoken language, while ăn is more prone to be invoked in written form.

$$
\begin{aligned}
& \text { (28) Julia ăn ră mǐdănest [ } \mathrm{S}^{\prime} \mathrm{ke} \text { zæmin gerd æst] } \\
& \text { OBJ it obj-marker } \mathrm{know}_{\text {(past) }} \mathrm{COMP}_{\text {(that) }} \text { Earth round is } \\
& \text { Julia knew that the Earth is round. }
\end{aligned}
$$

\section{Thetaless Expletives}

The claim that there exists an element called expletive in Persian still invokes a question why expletives, receiving no theta role, can occur in object positions or as objects of prepositions, which is contrary to the general position requirements. To resolve this dilemma, possible syntactic positions of expletives are to be verified. Expletives are generated in [SPEC CP] of an independent clause which receives no theta role. 
In the light of this conception the tree diagram for expletive $\iota_{n}$ in a subject position would be as the following:

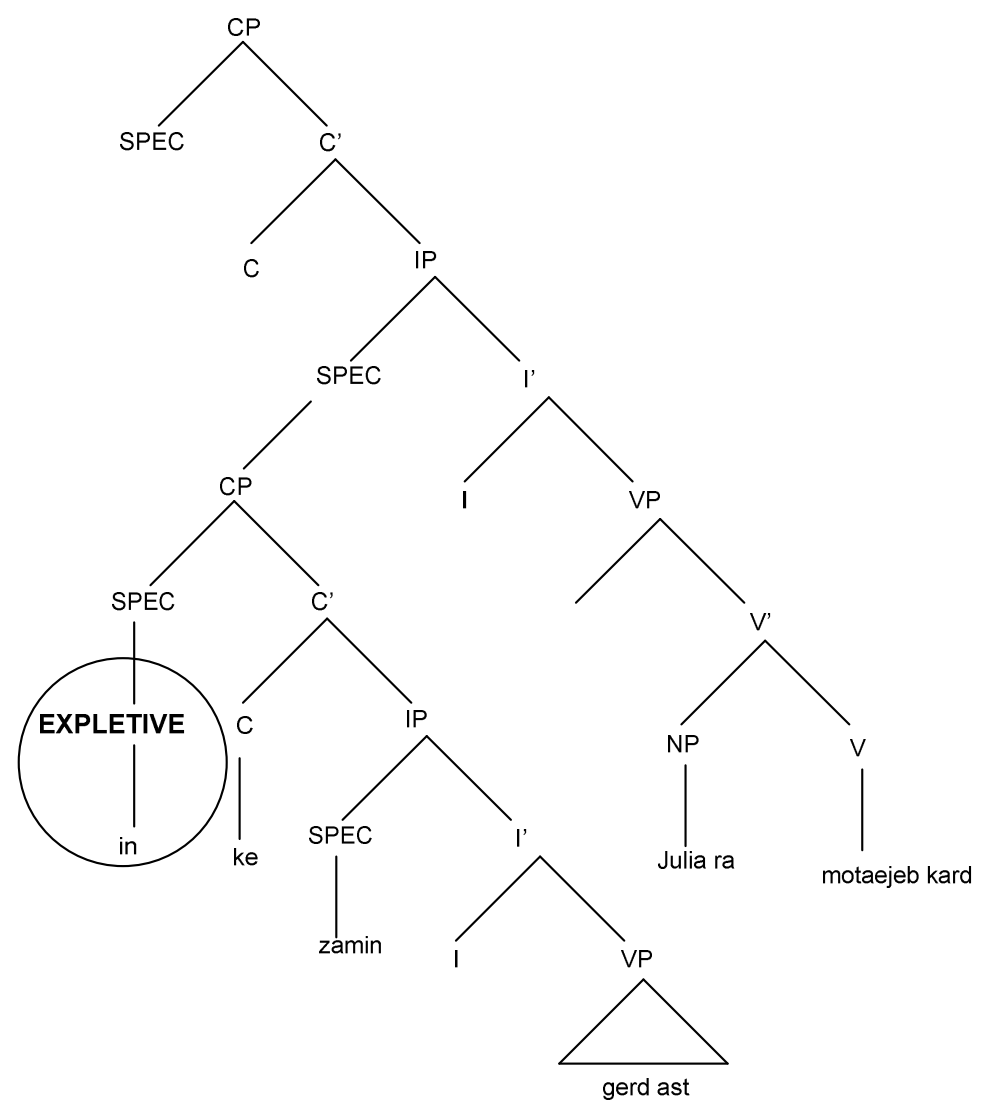

Figure 1: The expletive $\check{\iota n}$ in a subject position 
The next tree diagram shows the expletive $\check{~} n$ in an object position:

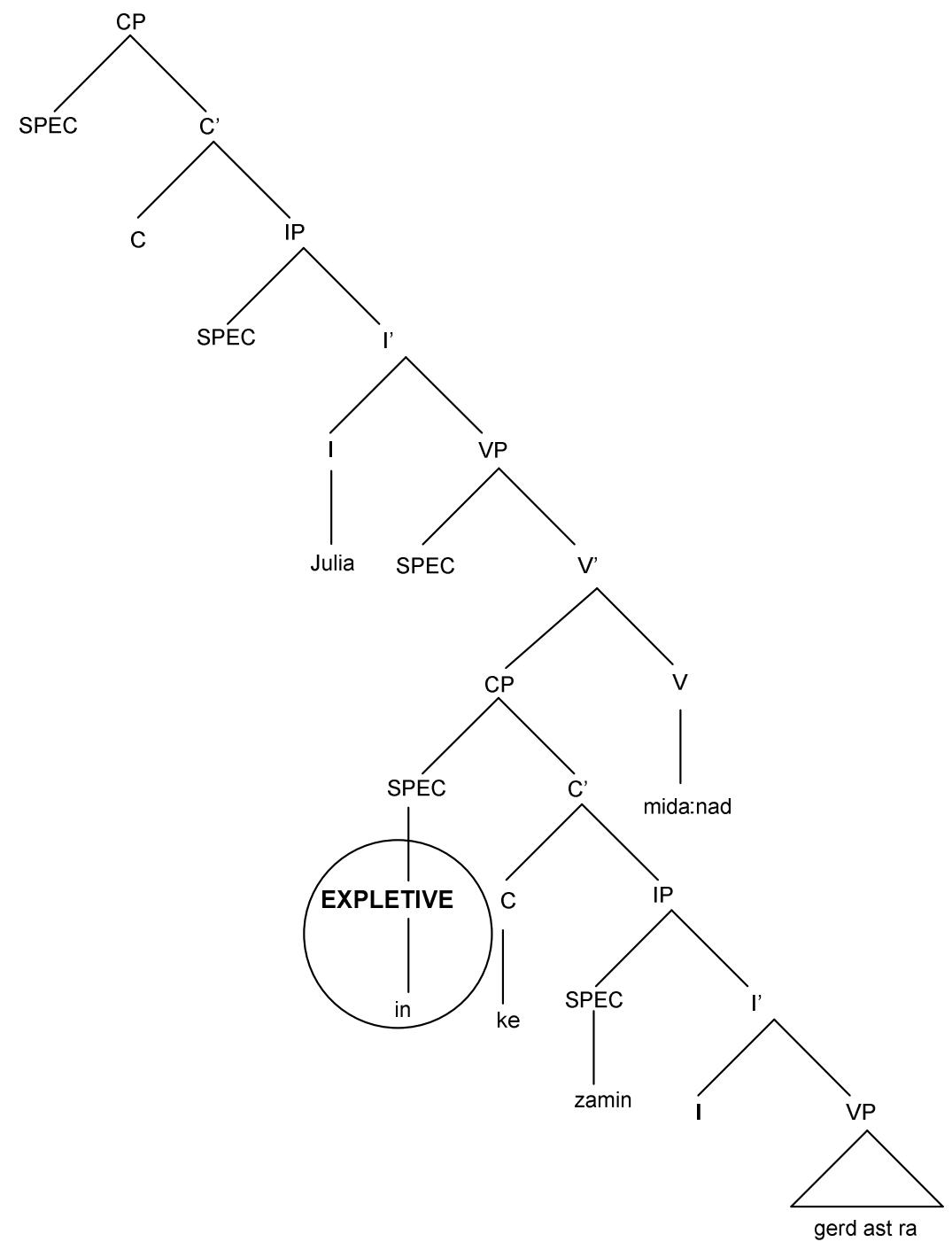

Figure 2: The expletive $\check{n} n$ in an object position 
Furthermore, the expletive $\check{\iota n}$ after a preposition would result in the following tree diagram:

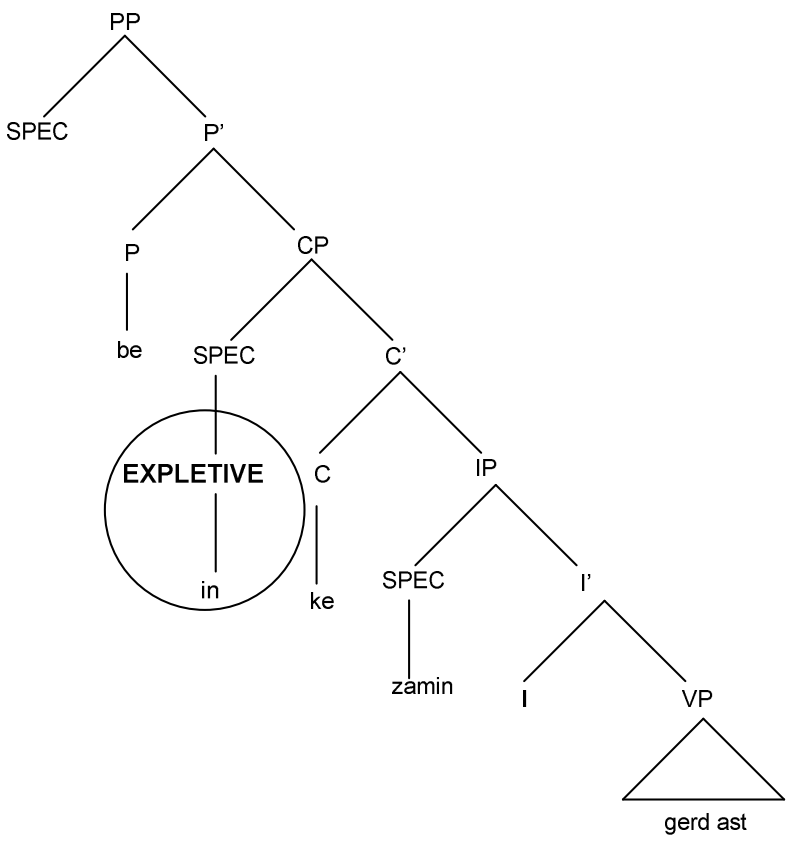

Figure 3: The expletive $\check{\iota n}$ after a preposition

Haegeman (1992, p. 55) proposes that expletives always turn up in a subject position, i.e. in the NP position for which the verb does not subcategorize. Indeed, expletives are elements lacking a theta role, and the theory predicts that expletives can only occur in NP positions that are not subcategorized for, i.e. subject position of a sentence.

\section{Conclusion}

Expletives are non-argument elements in NP positions to which no theta role is assigned. They may occur not only as subjects but also as objects. Their occurrence after prepositions is unlike the English structure where such position is ungrammatical. As expletives escape the theta role criterion, it is supposed that they are inserted into grammar after the theta criterion has filtered out the X-bar rules. It was argued that the reason for expletives being in background has its roots in morphological homophony of a similar but still different constituent as well as in the effect of how expletives are realized before complementizers in written form of Persian. 


\section{References}

Brandner, E. (1993): The projection of categories and the nature of agreement. In: G. Fanselow (Ed.) The parametrization of universal grammar (pp. 73-121). Amsterdam/Philadelphia: John Benjamins.

Burzio, L. (1986). Italian syntax. Dordrecht: Reidel.

Carnie, A. (2002). Syntax: a generative introduction. Oxford: Blackwell.

Chomsky, N. (1981). Lectures on Government and Binding. Dordrecht: Foris.

Chomsky, N. (1993). A minimalist program for linguistic theory. In K. Hale \& S. J. Keyser (Eds.), The view from Building 20. Cambridge, MA: The MIT Press.

Chomsky, N. (1995). The minimalist program. Cambridge, MA: MIT Press.

Groat, E. M. (1995). English expletives: a minimalist approach. Linguistic Inquiry, 26, 354-365.

Haegeman, L. (1992). Introduction to Government and Binding. Oxford: Blackwell.

Hurford, J. R., \& Heasly B. (1996). Semantics: a coursebook. Cambridge: Cambridge University Press.

Jackendoff, R. (1997). The architecture of the language faculty. Cambridge, MA: MIT Press.

Jackendoff, R. (2002). Foundations of Language: Brain, meaning, grammar, evolution. Oxford: Oxford University Press.

Karimi, S. (2005). A Minimalist Approach to Scrambling. Berlin: Mouton de Gruyter.

Koeneman, O., \& Neeleman, A. (2001). Predication, verb movement and the distribution of expletives. Lingua, 111, 189-233.

Lasnik, H. (1995). Case and expletives revisited: On greed and other human failings. Linguistic Inquiry, 26, 615-633.

Lyons, J. (1996). Linguistic semantics. Cambridge: Cambridge University Press.

Mahootian, S. (1997). Persian. London/New York: Routledge.

Miremadi, A. (1997). Persian Syntax: A GB-based Analysis. Tehran: SAMT Publishers.

Postal, P. M. \& Pullum, G. K. (1988). Expletive noun phrases in subcategorized positions. Linguistic Inquiry, 19, 635-670.

Reuland, E. (1988) Indefinite subjects. NELS, 18, 375-394. 